\title{
SIMON SEGAL - PRZYCZYNEK DO BIOGRAFII ARTYSTY
}

\section{Joanna TOMALSKA (Muzeum Podlaskie w Białymstoku)}

Gaston Bachelard, jeden z wybitnych współczesnych filozofów francuskich, we wstępie do wydanego w Genewie katalogu prac Simona Segala nazwał swego bohatera zbuntowanym aniołem ${ }^{1}$. Czym ów twórca, który nigdy nie ukończył akademii sztuk pięknych, zasłużył na to miano? W liście do Waldemara George’a tak wyjaśniał swoją twórczość:

Moja sztuka nie zrodziła się z podręczników. Jest swego rodzaju furtką do mego serca. Rezultatem bezpośredniego kontaktu z Naturą. Moja sztuka posiada ciało z miłości, jaką ofiarowałem kamieniowi, chmurze, kwiatom, źdźbłu trawy i każdej ludzkiej istocie. Ale ta sztuka jest również walką przeciw Naturze. Każde płótno jest małym wszechświatem rządzonym przez prawa plastyki. Każdy obraz jest początkiem, gwałtownym poszukiwaniem proporcji i pieśnią duszy.

La Hague uczyniło ze mnie malarza jakim jestem. W mojej bibliotece nie było żadnego dzieła sztuki, moje życie płynęło ociężale, a dni, pory roku i lata mijały powoli. La Hague wypełniło mnie swoją krwią. Wypełniło mnie energią. Zapomniałem o przeszłości. Walczyłem z moimi płótnami. Czasem kipiałem radością, czasem to złość stymulowała moją siłę. Oto jak odkryłem swój styl. Nigdy nie chciałem być podziwianym albo zadziwiać. Maluję, by usprawiedliwić mój pobyt na Ziemi i żeby uratować moją duszę ${ }^{2}$.

Jak wynika z zacytowanego fragmentu, żył sztuką i — jakkolwiek patetycznie to brzmi — sztuka była dla niego wszystkim.

Biografia pochodzącego z Białegostoku malarza kryje wiele tajemnic. Anna Wierzbicka w swojej książce École de Paris. Pojęcie, środowisko, twórczość przypomniała zasadnicze fakty z biografii Segala: miał rozpocząć studia inżynierskie w Rosji,

${ }^{1}$ W. George, Segal ou l'Ange Rebelle, Genève 1962, s. 7; ten tekst został powtórzony w późniejszych publikacjach filozofa; por.: G. Bachelard, Il Dritto di Sognare, Bari 1975, s. 37; tenże, The Right to Dream, Dallas 1988, s. 37.

${ }^{2}$ Tłum. E. Karczewska. 
w latach 1918-1924 przebywał w Berlinie, gdzie w tym czasie pracowali Ossip Lubitsch, Iwan Puni, Paul Tchelitchew i Leon Zack ${ }^{3}$. W 1923 lub 1925 roku wyjechał do Paryża, w 1926 roku zaś do Tulonu, tam zaprzyjaźnił się z Brunonem Bassano ${ }^{4}$, późniejszym marszandem. Już po wojnie, w latach 1946-1953, jego mecenasem był Henri Bernadi ${ }^{5}$. W 1953 roku malarz wrócił do Paryża, lecz często miał wyjeżdżać do Hagi; widoki tego miasta były częstym tematem jego dzieł. Po kilku latach pobytu w holenderskim mieście przyłączył się do międzynarodowej grupy artystów, określanej mianem École de Paris, których łączyły szczególne więzy towarzyskie i przyjacielskie. Członkowie tego nieformalnego kręgu wspierali się, przedstawiali marszandom, kolekcjonerom i mecenasom ${ }^{6}$.

Popularny słownik artystów żydowskich aktywnych w Paryżu podaje natomiast informację, że do 1924 roku artysta mieszkał w Berlinie, w następnym roku znalazł się w stolicy Francji, rok później zaś był już w Tulonie, gdzie pozostawał do 1933 roku$^{7}$.

Krótki biogram Simona Segala w innym źródle informuje, że miał studiować malarstwo w Warszawie, w 1920 roku znalazł się w Berlinie, później zaś w Paryżu ${ }^{8}$.

Biografia artysty zawiera wiele luk, nie wyjaśnia ich nawet w pełni wydana w 1974 roku autobiografia. Niewielki tomik, pisany w ostatnich miesiącach życia, ukazał się już po śmierci autora ${ }^{9}$. We wstępie poeta i krytyk Pierre Osenat tak wspominał Segala:

Obdarzony dziecięcą ciekawością życia, z palcami zażółconymi nikotyną, kochający muzykę i sztukę, niezależny, samotny, niewrażliwy na artystyczne mody, bezpośredni i niedbały odnośnie do materialnych warunków życia. Przy delikatności i wrażliwości zagubionego dziecka demonstrował egoizm zbuntowanego anioła. Zdaniem Osenata jego twórczość jest powrotem do źródeł, sztuką czystą, niewrażliwą na jakiekolwiek wpływy, swoistym aktem wiary, poszukiwaniem najbardziej pierwotnej prawdy o człowieku i naturze ${ }^{10}$.

Przy wszelkich zastrzeżeniach — nie wiadomo, na ile wiernie wydarzenia z przeszłości zapisały się w pamięci Segala, na ile zaś tekst jest autokreacją — autobiografia stanowi najpełniejsze źródło informacji o jego życiu. W Białymstoku - mieście, z którego pochodził artysta — nie zachowały się materiały potwierdzające ich prawdziwość,

\footnotetext{
${ }^{3}$ A. Wierzbicka, École de Paris: Pojęcie, środowisko, twórczość, Warszawa 2004, s. 31, s. 286.

${ }^{4}$ Bruno Bassano (1896-1978), kolekcjoner i marszand urodzony we Włoszech, większość życia spędził we Francji. W Paryżu pojawił się mając 27 lat, w 1928 przeniósł się do Tulonu. Po wyzwoleniu pracował jako dziennikarz i krytyk sztuki. Od 1951 ponownie znalazł się we Francji, w następnym roku otworzył galerię sztuki, promując przede wszystkim nieznanych artystów. W 1975 przekazał Pizie około trzystu obrazów w tym liczne obrazy Simona Segala oraz pracującego w Paryżu artysty pochodzenia tureckiego Fikreta Moualla (1903-1967), których dzieła szczególnie wysoko cenił; Simon Segal e la Scuola di Parigi, Donazione Bruno Bassano, Pisa 1975; S. Panichi, La Collezione Bruno Bassano, [w:] Pisa allo Specchio I Muzei e Collezioni Pisano, red. M. Buresi, A. Zampieri, Pisa 2012, s. 169-174.

${ }^{5}$ Henri Bernadi (1883-1970), zamożny kupiec z Cherbourga, kolekcjoner i powiernik artystów; w zbiorach, prócz dzieł Simona Segala, zgromadził prace Pierre'a Bonnarda, André Deraina, Éduarda Vuillarda; Ch. Zagrodzki, Hayden 1883-1970, Paryż 2013, s. 39.

${ }_{7}^{6}$ A. Wierzbicka, École de Paris, s. 31.

${ }^{7}$ N. Nieszawer, D. Princ, Jewish Artists of the School of Paris 1905-1939, Paris 2015, s. $301-303$.

${ }^{8}$ A. Darmon, Autour de l'art Juif: Peintres, sculpteurs et photographes, Paris 2003, s. 198.

${ }^{9}$ S. Segal, Autobiographie, Paris 1974.

${ }^{10}$ Tamże, s. 5-6, 149.
} 
zatem przy obecnym stanie badań będziemy się posiłkować wiadomościami w niej zawartymi.

Simon Segal urodził się 3 października 1898 roku w Białymstoku, gdzie jego ojciec prowadził sklep chemiczny. To on kupował synowi broszurowe wydawnictwa z okładkami zdobionymi rysunkami budzącymi wyobraźnię: był to pierwszy kontakt przyszłego artysty ze sztuką ${ }^{11}$. Epoka beztroskiego dzieciństwa zakończyła się w 1905 roku, kiedy cesarstwem wstrząsały nieomijające Białegostoku rewolucyjne wrzenia. W czerwcu 1906 roku doszło do tragicznych wydarzeń zakończonych masakrą ludności żydowskiej ${ }^{12}$. Warto przypomnieć jedną ze scen, jaką zapamiętał Segal:

Cała rodzina siedziała na podłodze na pierwszym piętrze obcego domu, w którym okna zostały starannie zasłonięte. Schronienia udzieliła im prawosławna mieszkanka kamienicy, sama zaś, stojąc w oknie z ikoną w wyciągniętych przed siebie dłoniach przekonała tłum, że w domu mieszkają tylko prawosławni. Kolejne dni pogromu rodzina przeczekała w Brześciu, po powrocie do Białegostoku zamieszkali w innej części miasta ${ }^{13}$.

Po latach Segal pisał o sobie jako nastolatku milczącym, samotnym i pogrążonym w marzeniach ${ }^{14}$.

Uczył się w białostockiej szkole realnej i w liceum francuskim ${ }^{15}$. Nauczyciel rysunku nie rozumiał, odnotował autor, malarstwa ani sztuki w ogóle, na lekcjach układał martwe natury z jabłkami i dzbanem, ustawiał gipsowe popiersia antycznych bóstw, uczniowie zaś musieli je odtwarzać. Prace przyszłego malarza nie spotkały się z akceptacją pedagoga i z reguły otrzymywał trójkę ${ }^{16}$.

Rodzice troszczyli się o możliwie wszechstronne wykształcenie syna, ojciec zatrudnił nauczyciela języka hebrajskiego i jazdy konnej, matka zaś nauczycielkę muzyki, która na zawsze zaszczepiła uczniowi zamiłowanie do tej dziedziny sztuki. Wakacje spędzał z rodzicami w kurortach niemieckich i szwajcarskich albo też na daczy pod Białymstokiem $^{17}$.

Wybuch wojny zaskoczył rodzinę w Berlinie. Podczas drogi powrotnej do Białegostoku. Zostali skierowani do obozu przejściowego, potem zaś zdecydowali się na przejazd pociągiem okrężną drogą przez Danię, Szwecję i Finlandię do Piotrogrodu i stamtąd do Białegostoku. Do celu nie dotarli, zatrzymując się na dłuższy czas w Twerze nad Wołgą, gdzie Segal kontynuował naukę w szkole realnej. Przygoda z kąpielą w Wołdze, która niemal zakończyła się utonięciem, uczyniła zeń, jak twierdził, fatalistę i człowieka przesądnego $^{18}$. Zapamiętał kilkutygodniową podróż do Astrachania, nad Morze Kaspijskie oraz wycieczki do Moskwy i Piotrogrodu, tam zwiedził Galerię Trietiakowską i Ermitaż, szczególną uwagę poświęcając impresjonistom i postimpresjonistom ${ }^{19}$.

Rodzice zdecydowali, że Segal podejmie studia politechniczne, lecz nie jest jasne, czy istotnie je rozpoczął, we wspomnieniach nie ma wzmianki na ten temat. Wkrótce po zakończeniu działań wojennych, otrzymawszy zezwolenie na powrót, Segalowie stawszy

${ }^{11}$ Tamże, s. 7.

${ }^{12}$ P. Korzec, Pogrom białostocki w 1906 r. i jego polityczne reperkusje, Rocznik Białostocki 1962 t. 3, s. 149-182; w ciągu trzech dni (14-16 czerwca) zginęło 88 osób, w tym 82 Żydów.

${ }^{13}$ S. Segal, Autobiographie, s. 9-10.

${ }^{14}$ Tamże, s. 11.

${ }^{15} \mathrm{Nie}$ udało się odnaleźć potwierdzenia istnienia takiej szkoły w mieście.

${ }^{16}$ S. Segal, Autobiographie, s. 14.

${ }^{17}$ Tamże, s. 12, 17.

${ }^{18}$ Tamże, s. 22.

${ }^{19}$ Tamże, s. 22-23. 
się obywatelami polskimi, wyruszyli przez Warszawę do rodzinnego miasta, wówczas już polskiego. Nie wiemy, czy Simon dotarł do celu, ze wspomnień wynika bowiem, że wprost z Warszawy, w której rodzina zatrzymała się na krótko, wyjechał z matką do Gdyni, stamtąd popłynął statkiem do Hamburga, a następnie pociągiem do Berlina ${ }^{20}$.

Segal zdecydowany na podjęcie kariery artystycznej zamieszkał w dzielnicy Wedding. Okres berliński stał się czasem rozrywek, na co zapewne wpłynęła atmosfera ówczesnego dekadentyzmu, który autor nazwał podmuchem szaleństwa. Do chwili nawiązania kontaktów z rosyjską emigracją pozostał sam ${ }^{21}$.

We wspomnieniach z okresu berlińskiego poświęcił akapit pismu „Spolochi” („Сполохи”), którego jednym z twórców był Aleksander Michajłowicz Drozdow ${ }^{22}$. Twórcy spotykali się, dyskutując o sztuce, w niedziele zaś bywali w domu kultury, gdzie zbierali się artyści z kręgu emigracji. W tym czasie Segal namalował obraz znany dziś z reprodukcji w pierwszym numerze pisma. Jego bohaterką stała się dziewczynka o skórze koloru kawy z mlekiem. Portret powstał w ciągu dwóch sesji, lecz po latach autor ocenił go bardzo krytycznie, jako niezgrabny, malowany raczej instynktownie niż $\mathrm{z}$ talentem i pozbawiony lekkości ${ }^{23}$.

Okres berliński był czasem poznawania muzeów i galerii, kontaktu ze sztuką Pabla Picassa, Georgesa Braque'a, Maurice'a Vlamincka, Marca Chagalla, Henriego „Celnika" Rousseau i Paula Klee. Segal namalował kilka obrazów (portretów i pejzaży), ponadto zaś napisał niewielką książeczkę o źródłach nowoczesnego malarstwa ${ }^{24}$.

W Berlinie w 1919 roku było około siedmiu tysięcy Rosjan, co miesiąc zaś przybywał kolejny tysiąc emigrantów ${ }^{25}$. Do 1923 roku miasto było nieformalną stolicą literacko-artystycznej emigracji rosyjskiej, funkcjonowały tu rosyjskie banki, sklepy, gazety i czasopisma, teatry i księgarnie, w 1921 roku powstał Dom sztuki (Дом искусств), rok później klub literacki. Członkowie i sympatycy (m.in. Aleksy Tołstoj i Ilia Erenburg) spotykali się w kawiarni Landgraf na Kurfürstendamm, potem w Café Leon, gdzie odbywały się poetyckie wieczory wybitnych pisarzy i poetów (m.in. Sergiusza Jesienina, Włodzimierza Majakowskiego i Borysa Pasternaka) oraz wykłady o kubizmie i futuryzmie. Oba kluby aktywnie działały do 1923 roku, kiedy z różnych przyczyn liczba emigrantów zaczęła się zmniejszać, Berlin, stopniowo tracąc na znaczeniu jednego z centrów rosyjskiej kultury, stał się przystankiem na drodze wiodącej dalej na Zachód albo Południe - do Paryża lub Pragi albo też z powrotem na Wschód ${ }^{26}$.

Pobyt Segala w Berlinie dobiegł końca w czasach inflacji2 ${ }^{27}$. Stąd wyjechał do Wiednia, gdzie od lat mieszkał jego wuj, aktor $\mathrm{Cezar}^{28}$. Do ważnych wydarzeń okresu

\footnotetext{
${ }^{20}$ Tamże, s. $29-30$.
}

${ }^{21}$ Tamże.

${ }^{22}$ Aleksander Michajłowicz Drozdow (1895-1963), pisarz rosyjski i sowiecki. W 1923, po zredagowaniu czternastu numerów „Spolochi” („Сполохи”), wrócił do ZSRS, redagowanie pisma przejął E. A. Gutnow, po dwudziestym pierwszym numerze przestało się ukazywać; $P y c$ ская литература ХХ века. Прозаики, поэты, драматурги. Биобиблиографический словарь, t. 1, Москва 2005, s. 654-656.

${ }^{23}$ S. Segal, Autobiographie, s. 33. Obraz nosił tytuł Mulatka (Полукровка).

${ }^{24}$ С. Сегаль, Современная живопись. Истоки и развитие, Берлин 1923; na okładce znalazła się reprodukcja pracy Alberta Gleizesa; Musée du Luxembourg, Simon Segal (1898-1969), [katalog wystawy], Paris 1989, s. 68.

25 В. В. Сорокина, Издательства и журналь, [w:] Русский Берлин, Москва 2003, s. $120-160$.

${ }^{26}$ Tamże.

${ }^{27}$ Tamże, s. 37. Segal zapewne wyjechał z Berlina w 1924 roku; por.: W. George, Segal, s. 41.

${ }^{28}$ S. Segal, Autobiographie, s. 39. 
wiedeńskiego autor zaliczył początek przyjaźni z Anatolijem Durowem ${ }^{29}$. Z perspektywy czasu stwierdził, że Wiedeń nie wzbogacił jego sztuki. Malował tu portrety w duchu akademickim o gładkiej lśniącej fakturze, ponadto projektował kostiumy teatralne i dekoracje dla baletu. W Wiedniu miała się odbyć pierwsza wystawa Segala - projektów kostiumów i scenografii - uznana po latach za porażkę ${ }^{30}$. Prace artysty $z$ tego czasu nie są dziś znane.

Twórca znalazł się w Paryżu z poznanym w Berlinie w 1925 roku malarzem ${ }^{31}$. Początki nie były łatwe, na krótko znalazł zatrudnienie w pracowni manekinów; w modzie tego czasu królowały pomysły awangardowego krawca Paula Poireta ${ }^{32}$, któremu Segal zaproponował swoje projekty, lecz zainteresowanie „króla” mody trwało bardzo krótko ${ }^{33}$. Simon zamieszkał w tanim hoteliku, zwiedzał Luwr i szukał pracy. Na miesiąc znalazł zatrudnienie jako księgowy, krótko pracował również jako robotnik w fabryce Citroëna ${ }^{34}$.

Wyjechał do Tulonu i zamieszkał w Mourillon, położonej nad morzem wschodniej dzielnicy miasta i zajął się malowaniem. Nie wiemy, dlaczego wybrał to miasto. Pierwsze obrazy w okresie tulońskim to mariny, martwe natury i portret starego rybaka ${ }^{35}$. Nawiązał kontakty z lokalnymi artystami, m.in. z Jose Mange' $\mathrm{em}^{36}$, którego żywe i barwne obrazy uczyniły na Segalu bardzo silne wrażenie oraz poetą Léonem Véran$\mathrm{e}^{\prime} \mathrm{em}^{37}$, malarzami Mariusem Echeviną ${ }^{38}$, Léonem Sabatierem ${ }^{39}$, Olive Tamarim ${ }^{40}$, Gabrielem Biancherim $^{41}$, Etienne Morillonem ${ }^{42}$, Willy Eisenschitzem ${ }^{43}$, André Mar-

${ }^{29}$ Anatolij A. Durow (1887-1928), treser, magik i akrobata rosyjski, debiutował w cyrku Riazaniu w 1914. W 1917 wyjechał do Niemiec, Francji, Włoch, w 1925 wrócił do ZSRS, zamieszkał w Taganrogu; w $1986 \mathrm{w}$ jego dawnym domu powstało poświęcone mu muzeum; ЭHииклопедия живой природы, t. 3, Москва 2006, s. 95.

${ }^{30}$ S. Segal, Autobiographie, s. 45.

${ }^{31}$ Tamże. Być może był to wspominany dalej Yohanan Simon.

32 King of Fashion: The Autobiography of Paul Poiret, London 2009; Fashion: The Collection of the Kyoto Costume Institute: A History from the $18^{\text {th }}$ to the $20^{\text {th }}$ Century, red. A. Fukai, Köln-London 2004, s. 332-333.

${ }^{33}$ S. Segal, Autobiographie, s. 46.

${ }^{34}$ Tamże, s. 48.

${ }^{35}$ Tamże, s. 53.

${ }^{36}$ Jose Mange (1866-1935), malarz impresjonista, w czasie studiów w Aix-en-Provence spotkał Paula Cézanne, pod którego wpływem pozostawał; B. Gaillard, Jose Mange 1886-1982, [katalog wystawy], Musee d'art de Tulon, Toulon 2003.

${ }^{37}$ Poeta Léon Verane we wspomnieniach wymienia przedstawicieli tulońskiego kręgu artystów: Leon Sabatier, Jose Mange, Eugene Baboulene, Jean-Paul Jacob, Simon Segal, Marius Echevin, Jacinto Salvado; punkt spotkań przyjaciół znajdował się w atelier Henri-Olive Tamari przy Place d'Armes; L. Verane, Toulon, Tulon 2007, s. 12.

${ }^{38}$ Marius Echevin (1899-1982), uczeń Antoine'a Bourdelle, przyjaciel Simona Segala i sąsiad Jose Mange, w 1923 wystawiał na Salon de Tuileries; E. Bénézit, Dictionnaire critique et documentaire des peintres, sculpteurs, dessinateurs et graveurs de tous les temps et tous les pays, red. J. Busse, t. 5, Paris 1999, s. 23.

${ }^{39}$ Leon Sabatier (1891-1965) malarz, uczył się w paryskiej École des Beaux Arts Decoratifs, autor pejzaży prowansalskich; Leon Sabatier 1891-1965: Exposition retrospective, [katalog wystawy], Tulon 1966.

${ }_{40}$ Olive Tamari (właśc. Henri-Olive Tamari, 1898-1980), malarz, grafik i poeta; M. Vincent, Le peinture des XIX et XX $X^{e}$ siècles, Lyon 1956, s. 353.

${ }^{41}$ Gabriele Biancheri (1901-1980), malarz; zob.: Moi, Gabriel Biancheri. Artiste et Peintre, http://www.gabrielbiancheri.com [dostęp: marzec 2015].

${ }^{42}$ Etienne Morillon (1884-1949), malarz, rysownik, autor pejzaży i martwych natur, przedstawiciel lyońskiej szkoły malarstwa i członek grupy Les Ziniars, wystawiającej w Lyonie w la- 
chandem $^{44}$, Maurice Savinem ${ }^{45}$, Hiszpanem Jacinto Salvado ${ }^{46}$, a także dyrektorem lokalnej galerii Brunonem Bassano, który stał się jedną z najważniejszych postaci w życiu Simona Segala. W trudnych chwilach wspierał go przyjaciel z okresu berlińskiego Yohanan Simon ${ }^{47}$.

Do ważnych postaci Tulonu należał Léon Verane. Segal namalował kilka portretów poety i jego żony - sprzedał je, będąc w trudnej sytuacji finansowej. W tymże czasie powstał znany dziś obraz przedstawiający osła ${ }^{48}$ namalowany na podstawie akwarelowego studium po powrocie z Korsyki. Dzieło spotkało się z uznaniem lokalnego krytyka, który „opisał zwierzę z pochylonym łbem większym niż korpus, melancholijne i zrezygnowane, czekające nie wiedzieć na co, jakby spadły nań wszystkie nieszczęścia świata",49.

Jednym z sąsiadów Segala w Tulonie był starszy o pokolenie malarz Otton Friesz, z którym Segal doskonale się rozumiał. W tym czasie sprzedał kilka swoich obrazów, co zaliczył do pierwszych poważnych transakcji w życiu ${ }^{50}$. W Tulonie powstały prace, które po latach uznał za dobre - płótna i akwarele, rysunki i gwasze z przedstawieniem ludowych festynów, z żonglerami i akrobatami oraz kilka portretów ${ }^{51}$.

Nie wiadomo, jak długo trwał pobyt artysty w Tulonie ${ }^{52}$. Po kilku latach (prawdopodobnie w 1933 roku) wrócił do Paryża i zajął mieszkanie przyjaciela, Yohanana Simona, w kamienicy przy 7 L'Impasse de Rouet w XIV dzielnicy, w której mieszkali artyści różnych specjalności i pochodzenia: Japończycy, Holendrzy, Niemcy, Hiszpanie i kilku Francuzów ${ }^{53}$. Segal, znowu bez powodzenia, próbował podjać jakąkolwiek pracę.

Swą przyszłą żonę Genevieve (zwaną we wspomnieniach „Nie”) poznał w pierwszych tygodniach wojny ${ }^{54}$. To ona skłoniła Segala do wyjazdu z Paryża i towarzyszyła mu w tułaczce. Artysta zapisywał nie tylko trasę tej wędrówki, lecz także wrażenia i widoki, co pozwoliło mu później precyzyjnie odtworzyć drogę przebytą od 13 lipca do 30 września, kiedy dotarli do Aubusson ${ }^{55}$. W tym czasie poślubił Genevieve i mimo

tach 1920-1924; D. Festaud-Mermillon, Les Ziniars (1920-1924), [katalog wystawy], Musée des beaux-arts de Lyon, Lyon 1976.

${ }^{43}$ Willy Eisenschitz (1889-1974), malarz francuski pochodzenia austriackiego, autor prowansalskich pejzaży, w latach 1921-1922 mieszkał w Prowansji; pozostawał pod silnym wpływem Cézanne'a; B. Denver, Willy Eisenschitz: Colour and Form in $20^{\text {th }}$ Century Painting, East Petersburg 2005.

${ }_{44}$ André Marchand (1907-1997), malarz; zob.: M. Bépoix, André Marchand, Musée de Morlaix 18.06-6.11. 2010, [katalog wystawy]; Chevau-Legers - Enchères, Dimanche 23. X. 2011, Tableaux, dessins, sculptures $X I X^{e}-X X^{e}$ et contemprains [katalog aukcyjny], Versailles 2011, s. 32-41.

${ }^{45}$ Maurice Savin (1894-1973), malarz, ceramik, grafik; Maurice Savin: exposition Musée d'art moderne de la ville de Paris, 8 février - 18 mars 1979 [katalog wystawy], Paris 1979.

46 Jacinto Salvado (1892-1983), malarz, portretowany przez Pabla Picassa w 1923 roku w przebraniu arlekina; Jacinto Salvado, Tapa blanda [katalog wystawy], Madryt 2002.

${ }^{47}$ Yohanan Simon (1905-1976), malarz, od 1927 roku przebywał w Paryżu, w 1936 roku przeniósł się do Tel Awiwu; J. Castagno, Jewish Artists' Signatures and Monograms, Plymouth 2010, s. 437.

${ }_{48}$ Obraz, eksponowany na białostockiej wystawie Simona Segala, znajduje się obecnie w zbiorach prywatnych w Niemczech.

${ }^{49}$ S. Segal, Autobiographie, s. 56.

${ }^{50}$ Tamże, s. 61.

${ }^{51}$ Tamże, s. 65.

${ }^{52}$ Zapewne przebywał w Tulonie w latach 1926-1933; W. George, Segal, s. 41.

${ }^{53}$ S. Segal, Autobiographie, s. 68.

${ }^{54}$ Tamże, s. 80.

${ }^{55}$ Tamże, s. 84-99. 
bardzo trudnych warunków malował, co dawało mu poczucie wolności. Wkrótce urodziła się ich jedyna córka Lucie ${ }^{56}$.

W czerwcu 1940 roku wielu mieszkańców Paryża wyruszyło na południe kraju, jak pisał Andrzej Bobkowski: „Na pewno nikt nie wiedział, dokąd idzie. Szli bez celu, byle przed siebie, bo inni szli. Opętani, zatruci trucizną ucieczki”,57. W tym tłumie znalazł się też Simon Segal i jego przyszła żona.

W 1943 roku Segal pracował jako pomocnik rysownika w warsztacie gobelinów, lecz musiał przerwać pracę ze względu na konieczność ukrywania się, najpierw na farmie, później zaś, za namową swego ucznia René Legranda — w jego paryskiej pracowni ${ }^{58}$.

Cytowany już Andrzej Bobkowski odnotował w czerwcu 1942 roku, że atmosfera Paryża stwarzała pozory miasta niezajętego przez okupanta:

Jeszcze ciągle mamy swobodę — już ukróconą, ale zupełnie możliwą [...]. Tu wolno jeszcze nie tylko myśleć, ale mówić ${ }^{59}$.

Nieco później zaś, w sierpniu 1942 roku:

Wyłapywanie Żydów obcokrajowców na terenie Paryża zostało zakończone. Z 14 na 15 lipca urządzono taką noc św. Bartłomieja, a właściwie św. Adolfa, potem łapano resztki — obecnie na terenie całej strefy okupowanej wszyscy Żydzi obcokrajowcy zostali powsadzani do obozów ${ }^{60}$.

To wtedy w malarstwie Segala pojawiły się nowe elementy. Odnotował, że odczuł wówczas chęć odcięcia się od wcześniejszych sposobów ekspresji i przekonań, zapragnął zacząć wszystko od początku i zdając się na instynkt i intuicję — znaleźć własny język $^{61}$. W paryskiej pracowni spędził dziewięć miesięcy, w tym czasie powstał m.in. znany obraz artysty Chłopiec z kogutem $^{62}$ oraz podwójny portret żony i córki; artysta zarzucił próby malowania dzieł abstrakcyjnych, uznawszy, że ten nurt jest zbyt daleki od jego temperamentu ${ }^{63}$.

Latem 1945 roku wyjechał z rodziną do Creuse, rok później zaś zdecydowali się opuścić Paryż i zamieszkać na normandzkim przylądku La Hague nad Kanałem La Manche, który dla Simona był dzikim rajem, tu powstały obrazy malowane żywymi plamami barw podkreślone śmiałym konturem ${ }^{64}$. Uwieczniał przede wszystkim dzieci, w tej epoce powstały sztandarowe obrazy Gisele, Francine z psem, Maurice z obręcza oraz pierwsze martwe natury z La Hague. Do 1948 roku została stworzona znacząca liczba portretów, wizerunków zwierząt i martwych natur malowanych nowym językiem malarskim. Obrazy te przedstawił swemu przyjacielowi Henriemu Bernadi ${ }^{65}$.

Osobistą tragedią malarza stało się rozstanie z żoną. Wrócił po nim do Paryża, gdzie Bruno Bassano otworzył małą galerię przy Rue Gregoire-de-Tours ${ }^{66}$. Nie znamy przyczyn rozpadu rodziny, lecz bez wątpienia był to dla artysty silny wstrząs.

\footnotetext{
56 Tamże, s. 106.

${ }^{57}$ A. Bobkowski, Szkice piórkiem, Warszawa 2011, s. 19; notatka z 12 czerwca 1940.

${ }^{58}$ S. Segal, Autobiographie, s. 109-111.

${ }^{59}$ A. Bobkowski, Szkice piórkiem, s. 301.

${ }^{60}$ Tamże, s. 305.

${ }^{61}$ S. Segal, Autobiographie, s. 114.

${ }^{62}$ Tenże, Jeune homme au coq, 1949; Musée du Luxembourg, Simon Segal 1898-1969, s. 21.

${ }^{63}$ Tenże, Autobiographie, s. 115.

${ }^{64}$ Tamże, s. 116 i n.

${ }^{65}$ Tamże, s. 120

${ }^{66}$ Tamże, s. 135
} 
Latem 1956 roku Bassano i Segal wybrali się do prowansalskiego Aups, w następnym zaś roku do włoskiego miasteczka Sarzana, rodzinnej miejscowości Bassano. W czasie podróży powstało wiele szkiców rysunkowych toskańskich pejzaży i widoków Sieny, na ich podstawie Segal namalował obrazy olejne i gwasze ${ }^{67}$.

W ostatniej dekadzie życia wiele podróżował. Był w Holandii, gdzie podziwiał dzieła Rembrandta, Vermeera i van Gogha, odnotował zachwyt nad barwą holenderskiego nieba, zwiedził Florencję, Asyż, Rawennę, Padwę, Pizę, Weronę, wreszcie Madryt i Toledo ${ }^{68}$.

Simon Segal zmarł trzy miesiące po oddaniu rękopisu autobiografii przyjacielowi. Został pochowany na cmentarzu w Arcachon. Na jego nagrobku widnieje prosty napis „Simon Segal Artiste - Peintre”.

Po latach Bruno Bassano przekazał Pizie kolekcję dzieł sztuki złożoną z blisko trzystu prac ${ }^{69}$. Wśród nich znajdowały się obrazy olejne, gwasze, akwarele i rysunki Simona Segala.

W 1977 roku ten sam kolekcjoner przekazał pięćdziesiąt sześć prac Simona Segala miastu Aups, gdzie w 1980 roku w dawnej kaplicy klasztoru urszulanek powstało Muzeum Simona Segala ${ }^{70}$. Tu wśród dzieł przedstawicieli trzech szkół malarskich — Tulonu, Bourges i Paryża — znalazły swe miejsce obrazy Simona Segala podarowane przez Brunona Bassano.

Segal był autorem wielu wystaw indywidualnych, brał też udział w licznych ekspozycjach zbiorowych. Jeśli nie liczyć nieznanej bliżej galerii projektów scenografii w Wiedniu, zadebiutował na zbiorowym pokazie w galerii Trident w Tulonie w 1929 roku $^{71}$, na prezentację indywidualną musiał czekać jeszcze kilka lat. W czasie półrocznej pracy w 1935 roku stworzył ponad dwieście gwaszy malowanych czerwieniami i żółcieniami, łamanymi metaliczną szarością ${ }^{72}$. Trzydzieści prac z tego cyklu przedstawił na wystawie w okrągłej sali Galerii Billet-Worms, ekspozycja — wedle słów autora - stała się rodzajem filmu składającego się z zatrzymanych kadrów ${ }^{73}$. Wystawie towarzyszył katalog, do którego Simon Segal napisał krótki wstęp ${ }^{74}$. Wszystkie prace kupił amerykański kolekcjoner Frank Altschul ${ }^{75}$, zaś sukces mało znanego artysty odnotowała paryska prasa ${ }^{76}$.

Zbiorowa ekspozycja w Galerie Zak trwała krótko: 26 czerwca - 10 lipca 1936 roku $^{77}$. Jej organizacją zajął się związek repatriantów rosyjskich; wszyscy uczestnicy, stwierdził anonimowy autor krótkiego wstępu, zaliczają się do międzynarodowej grupy École de Paris, zaś wśród czterdziestu dwóch wymienionych artystów znaleźli

${ }^{67}$ Tamże, s. 136 i n.

${ }^{68}$ Tamże, s. 145-146.

${ }^{69}$ A. Tossi, Simon Segal e La Scuola di Parigi, Donazione Bruno Bassano, Museo Nazionale di S. Matteo, Maggio 1975 [katalog wystawy], Pisa 1975.

${ }^{70}$ Simon Segal et l'École de Paris, Donation Bruno Bassano, Ville d'Aups 1977.

71 Simon Segal 1898-1969, [katalog wystawy]. Paris, Musée du Luxembourg, [Cour Cheverny 1989] s. 8.

${ }^{72} \mathrm{~W}$ autobiografii powstanie tego cyklu Segal przypisał swoistemu „,przeczuciu wojny”; Segal, Autobiographie, s. 72 i n.

${ }^{73}$ Tamże.

${ }^{74}$ Katalogu wystawy nie udało się dotychczas odnaleźć.

${ }^{75}$ S. Segal, Autobiographie, s. 73.

${ }^{76}$ C. Roger-Marx, Compte rendu des expositions, Le Jour, 05.12.1936, s. 6.

77 Artistes Russes, exposition organisèe par la revue Notre Union du 26 juin au 10 juillet 1936, vernissage le vendredi 26 juin à 15 heures, Galerie Zak, 15 rue de l'Abbaye (Place SaintGermain-des-Prés), [folder wystawy]. 
się: Benn (zapewne Benn Rabinowicz), Marc Chagall, Alexandra Exter, Pinchus Krémègne, Robert Pikelny, Chaim Soutine, Lazar Volovick i Simon Segal ${ }^{78}$.

Po 1933 roku malarz brał udział w Salonach Jesiennych (1933, 1934, 1937-1939) oraz w Salonach Tuileries (1937-1939) ${ }^{79}$.

Druga indywidualna ekspozycja artysty miała miejsce w 1950 roku w galerii Drouant David $^{80}$. Rok później wziął udział w wystawie w Tulonie, zaś w 1953 roku przedstawił w galerii Brunona Bassano około trzydziestu obrazów (w tejże galerii odbyły się wystawy artysty w 1954 i 1955 roku $^{81}$ ). W tym samym roku zaprezentował się też w La Spezia we Włoszech. Kolejnej, w 1956 roku w Musée Toulouse-Lautrec w Albi, gdzie pokazał gwasze z La Hague i Paryża oraz tkaniny, towarzyszył katalog ze wstępem Waldemara George'a ${ }^{82}$. W 1957 roku wziął udział w dorocznym Salon des Peintres témoins de Leur Temps zorganizowanym przez Brunona Bassano ${ }^{83}$.

Na przełomie 1959 i 1960 roku w paryskim muzeum Antoine Bourdella odbyła się wystawa $\mathrm{z}$ udziałem Simona Segala w nietypowej dla artysty roli ${ }^{84}$. W 1957 roku poznał młodego brazylijskiego artystę Antonio Carelli ${ }^{85}$ i spróbował swoich sił w mozaikach. Brazylijczyk wynająwszy pracownię w Puteaux na zachodnich przedmieściach Paryża, zaproponował Segalowi przeniesienie motywów z tkanin na mozaiki. Jako pierwsza powstała wielka praca $\left(12 \mathrm{~m}^{2}\right)$ zatytułowana Ognisty wą̇̇ (Le serpent à plumes), inspirowana sztuką meksykańską. Simon Segal najwyżej cenił równie okazałą mozaikę Śmierć (La mort) ${ }^{86}$ ze starą kobietą, ruinami domu i wynędzniałym koniem.

Janine Auscher odnotowała, że na murach ogrodu na Montparnasse znalazły się cztery dzieła młodego brazylijskiego artysty, wykonane na podstawie makiety malarza École de Paris, Simona Segala ${ }^{87}$. Przeznaczone dla São Paulo, zostały najpierw pokazane w paryskim Musée Bourdelle, ponieważ francuski rzeźbiarz interesował się szczególnie muralami, w pierwszym rzędzie zaś tymi, które wiązały się ze szkołą

${ }^{78}$ Tamże, s. [nlb. 3]; nie podano imion uczestników wystawy.

${ }^{79}$ W. George, Segal, s. 46.

${ }^{80}$ Simon Segal 1898-1969, s. 8. Paryska galeria Drouant-David została założona w 1942, przy Faubourg Saint-Honoré przez prawnika Emmanuela Davida i malarza Armanda Drouanta, tu pokazano wystawy Henryka Haydena, Mojżesza Kislinga, Leonor Fini i wielu innych; działała do 1958 r.; J. Krasnodębska, ,Angielka w Paryżu”. Listy Haliny Korn-Żuławskiej do męża (maj - czerwiec 1950), Archiwum Emigracji. Studia — Szkice — Dokumenty 2012 z. 16-17, s. 168, przyp. 56.

${ }^{81}$ S. Segal, Autobiographie, s. 135; W. George, Segal, s. 45.

82 Waldemar George (właśc. Jerzy Waldemar Jarociński, 1893-1970), urodzony w Łodzi krytyk francuski, uważany za odkrywcę sztuki wielu przedstawicieli Ecole de Paris, korespondent „Wiadomości Literackich”; Y. Chevrefils Desbiolles, Le critique d'art Waldemar-George. Les paradoxes d'un non-conformiste, Archives Juives 2008 t. 41, s. 101-117.

${ }^{83}$ Simon Segal 1898-1969, s. 8.

${ }^{84}$ M. Dufet, [wstęp w:] Mosaïques, Art Mural, Simon Segal, Antonio Carelli, Museé Bourdelle 19.11.1959-10.01.1960, [katalog wystawy]. Mozaika Śmierć trafiła do prywatnych zbiorów Norberta Krautmana.

${ }^{85}$ Musée Bourdelle, Mosaïques, art mural, Simon Segal, Antonio Carelli du 19 novembre 1959 au 10 janvier 1960 [katalog wystawy]. Antonio Carelli studiował w Rawennie, zafascynowany starymi technikami podjął próbę ich dogłębnego poznania, często bywał w Galerie Bassano, gdzie zapewne poznał Simona Segala. tkaniny.

${ }^{86}$ Simon Segal, La mort, [w:] Simon Segal 1898-1969, s. 57. Pierwotnie karton był wzorem

${ }^{87}$ J. Auscher, Expositions parisiennes: curieuses mosaïques au Museé Bourdelle, Le mouvement féministe: organe officiel des publications de l'Alliance nationale des sociétés féminines suisses, $1960 \mathrm{nr} 875$, s. 2 . 
w Rawennie (gdzie Carelli studiował tajniki mozaik). Wszystkie prezentowane prace Antonio Carelli wywiózł do Brazylii, gdzie pozostały ${ }^{88}$. W 1960 roku przedstawiono je na wystawie w Museu de Arte de São Paulo ${ }^{89}$. Auscher zauważyła w dziełach dwa źródła inspiracji: sztukę meksykańską i francuską. Do pierwszej zaliczyła dwa dzieła: Ognisty waż i Zaklinacz ptaków (Le charmeur d'oiseaux), pozostałe dwa to La Hague i Śmierć. O tej ostatniej pracy wiemy, że powstała pod koniec pobytu w La Hague ${ }^{90}$.

Początek lat 60. zaowocował większą liczbą wystaw: w 1961 roku płótna, gwasze i ilustracje Segala przedstawiła londyńska Upper-Grosvenor Galleries, w 1963 roku zostały pokazane w Galerie Stendhal w Mediolanie, w następnym zaś w galerii Bassano, wreszcie ostatnia wystawa przed śmiercią została wyeksponowana w galerii Drouant ${ }^{91}$.

Dwa lata po śmierci artysty w 1971 roku odbyła się retrospektywna prezentacja jego prac w Breście w Palais des Arts et de la Culture, w następnym roku w Valréas, po dziesięciu zaś, w 1982 roku w paryskim Salons de la Rose-Croix ${ }^{92}$. Prawdopodobnie największa ekspozycja miała miejsce w Musée de Luxembourg w Paryżu w 1989 roku, gdzie pokazano 160 prac $^{93}$. Znacznie mniejsze wystawy odbyły się w 1990 roku w Paryżu, w 1997 roku w Arcachon oraz w 1999 roku w Cherbourgu. Do bardziej okazałych należy zaliczyć pierwszą polską wystawę artysty, która miała miejsce w 2010 roku w Muzeum Podlaskim w Białymstoku, gdzie pokazano dziewięćdziesiąt dzieł malarza ${ }^{94}$.

Nie znamy wszystkich meandrów rozwoju artystycznego Simona Segala, on sam twierdził, że pobyt w La Hague uczynił zeń malarza. Warto zatem zadać pytanie, jak malował wcześniej. Najsłabiej znane są prace artysty z okresu berlińskiego: w kilku numerach pisma „Spolochi” znalazły się jego na poły amatorskie ilustracje, w których — prócz zacięcia satyrycznego — jest widoczny talent bystrego obserwatora ${ }^{95}$.

Odmienny od późniejszych płócien, jedyny znany dziś obraz artysty z tego czasu, powstał zapewne około 1923 roku i nosi tytuł Maski ${ }^{96}$. Jego dolną cześć zajmuje owalna różowa pozbawiona wyrazu twarz-maska o szeroko otwartych oczach i uniesionych żółtych brwiach oraz duży szaroniebieski dzban. Namalowane płaską plamą barwną przy użyciu skontrastowanych odcieni różu, chromowej zieleni, czerwieni i brązu.

Segal dość wcześnie zaczął malować portrety. Jeden z najstarszych dziś znanych, Portret Brunona Bassano z 1929 roku, przedstawia popiersie młodego człowieka o krótkich, ciemnych włosach, wyrazistych ciemnych brwiach i ciemnych oczach ze spojrzeniem skierowanym ku górze ${ }^{97}$. Jest malowany grubym czarnym konturem określającym barwne plamy rozświetlonej ugrem partii wysokiego czoła i kobaltowozielonego niejednolitego tła. Analogiczne cechy nosi dzieło Czaszka przy oknie z uka-

\footnotetext{
${ }^{88}$ S. Segal, Autobiographie, s. 142.

${ }^{89}$ Simon Segal 1898-1969, s. 8.

${ }^{90}$ Auscher, Expositions parisiennes, 1. c.

${ }^{91}$ Simon Segal 1898-1969, s. 8.

${ }^{92}$ Tamże.

${ }^{93}$ Tamże.

94 Simon Segal (1898-1969), Tajemnicze dziecko Biategostoku, Wystawa eksponowana w Muzeum Podlaskim w Białymstoku 18 VI - 5 IX 2010 [zestaw pocztówek].

${ }^{95}$ Simon Segal, Fragment ilustracji z pisma „Spolochi” (1922 nr 6), [w:] Simon Segal 1898

${ }^{96}$ Simon Segal, Maski (Les masques), olej; obraz jest jedynym znanym dziełem Segala z okresu berlińskiego, obecnie w zbiorach w Aups; tamże.

${ }^{97}$ Simon Segal, Portret Brunona Bassano (Portrait de Bruno Bassano), 1929, $46 \times 55$, zbiory M. B. Bassano, Paryż; W. George, Segal, il. 1. Barwna reprodukcja zob.: Simon Segal (18981969), Cherbourg 1999, s. 12.
} 1969, s. 15. 
zanym z prawego boku tytułowym detalem na pierwszym planie ${ }^{98}$. Z tego czasu pochodzi malowany subtelniej Portret pani Caffarena z postacią siedzącej ciemnowłosej młodej kobiety zwróconej trzy czwarte w prawo, z rękoma złożonymi na kolanach ${ }^{99}$.

Późniejszy gwasz bez tytułu pochodzący z około 1935 roku z kolekcji Leopolda Mittmana przedstawia pozbawiony cech indywidualnych szary thum obok nieokreślonego straganu na tle szarych wysokich kamienic pod brudnoszarym niebem. Został namalowany szybkimi, gwałtownymi pociągnięciami pędzla z nielicznymi akcentami złamanej czerwieni i rozbielonych zieleni w partii straganu ${ }^{100}$.

Bohaterem obrazu Rybak jest siedzący masywny mężczyzna w ujęciu wprost o rękach splecionych na wysokości piersi, o grubych rysach i skórze o żółtawym odcieniu. Obok głównej postaci z prawej strony znalazła się szkicowo potraktowana głowa kobiety, z lewej słabo określona półpostać w czerwonej czapeczce. Obraz został namalowany zgaszonymi barwami grubym, ciemnym konturem ${ }^{101}$.

Zdaniem krytyków lata 1936-1939 to okres pesymizmu. Segal malował wtedy ludzi robotników, ludzi z marginesu i żebraków ${ }^{102}$.

W latach 1944-1945 artysta zmienił paletę barw, miejsce ciemnych, zgaszonych kolorów zajęły jasne rozbielone błękity, ultramaryny, czerwienie, żółcienie i żywe zielenie. Jak sam zapisał w autobiografii był to okres radykalnego zerwania $\mathrm{z}$ malarską przeszłością, koncepcją obrazu, własnymi przyzwyczajeniami i dotychczasowym sposobem ekspresji ${ }^{103}$. Z 1949 roku pochodzi obraz Diénis przy stole z półpostacią mężczyzny wspierającego głowę lewą dłonią, malowany z całkowitym lekceważeniem szczegółów i perspektywy oraz zestawieniem błękitu pruskiego, rozbielonej żółcieni i odcienia ciemnopomarańczowego w partii blatu stołu ${ }^{104}$. Stylistyka obrazu przypomina — jak wiele późniejszych dzieł Simona Segala — twórczość dzieci, z jej daleko idącymi uproszczeniami, prostotą form i żywymi barwami.

Do ważnych w swoim życiu obrazów autor zaliczał zbiorowy portret pięciu zakonnic zatytułowany Zakonnice ${ }^{105}$. W autobiografii odnotował, że około 1957 roku poznał siostrę Klotyldę, został zaproszony do klasztoru Lisieux, zaś zakonnice pozowały jedna po drugiej co zapewne wpłynęło na blisko dziesięcioletni czas pracy nad portretem.

Segal podejmował eksperymenty $\mathrm{w}$ grafice, tkaninie, mozaice i ceramice, w 1957 roku dla wydawnictwa Labergerie stworzył cykl czterdziestu dwóch ilustracji

\footnotetext{
${ }^{98}$ Simon Segal, Czaszka przy oknie (Crâne sur la Fenêtre), $54 \times 65$, zbiory M. B. Bassano, Paryż; tamże, il. 2.

${ }_{99}$ Simon Segal, Portret pani Caffarena (Portrait de Mme Caffarena), płótno, zbiory prywatne, Tulon, [w:] Simon Segal 1898-1969, s. 15.

${ }^{100}$ Simon Segal, bez tytułu (Scena uliczna), ok. 1935, papier, gwasz, 50,8 $\times$ 65,4, sygn. 1.d.; Leopold Mittman otrzymał tę pracę ok. 1938 od jej autora; S. Loughrey, E. Portanova, Z. Weinberg, P. des Marais, Los Angeles Modern Auctions, 19. V. 2013, [katalog aukcyjny], Los Angeles 2013, nr kat. 104. Leopold Mittman - europejski pianista, akompaniator wielu wybitnych skrzypków, z którymi koncertował na całym świecie, w latach 30. studiował w berlińskiej Hochschule für Musik, w późniejszych latach opuścił Niemcy i przeniósł się do USA; I. Stern, A. Potok, Isaac Stern: My First 79 Years, Boston 1999, s. 35.

${ }^{101}$ Simon Segal, Fisherman, 1940, płótno, olej, 76,2 × 63,5, sygn. 1.d.; Rose Hill Auction Gallery, 19 XI 2007, nr kat. 5218; http://www.liveauctioneers.com/catalog/14274/page11?row$\mathrm{s}=20$ [dostęp marzec 2015].

${ }^{102}$ Simon Segal 1898-1969, s. 8.

${ }^{103}$ S. Segal, Autobiographie, s. 113.

${ }^{104}$ Simon Segal, Diénis à table, 1949; Simon Segal (1898-1969), s. 24.

${ }^{105}$ Simon Segal, Seurs de la Providence, 1959-1968, Genia Schreiber University Art Gallery Tel Aviv; Simon Segal 1898-1969, s. 48-49.
} 
do Biblii ${ }^{106}$, w roku śmierci artysty zaś ukazał się bibliofilski wydany w stu dwudziestu numerowanych egzemplarzach tom ilustracji do Apokalipsy według św. Jana zawierający szesnaście litografii Segala ${ }^{107}$.

Simon Segal kilkakrotnie zmienił sposób malowania: od płaskich, dekoracyjnych form okresu berlińskiego, poprzez ciemne, pełne dramatyzmu portrety tulońskie, do kumulacji ekspresji w latach 30., gdy z Tulonu wrócił do Paryża. Za sztandarowe dzieło tego okresu uznał cykl Wizje wojny (Visions de guerre) właściwie nieznany w Euro$\mathrm{pie}^{108}$. Z tej epoki pochodzi gwasz Żebracy z trzema postaciami, malowanymi szeroko, bez cienia dbałości o szczegó ${ }^{109}$. Sam artysta twierdził, że był to okres walki o ludzi skrzywdzonych, ubogich, pozbawionych nadziei. Obrazy malowane są ciemnymi barwami, szeroko, z pozostawieniem śladów pędzla, często z chropawą fakturą ${ }^{110}$.

Okres wypracowania własnej drogi przypada na lata 1946-1953, kiedy malował przede wszystkim dzieci. Z 1947 roku pochodzi Mały Normandczyk, rudowłosy chłopiec o jasnych oczach, ze splecionymi rękoma o brudnych dłoniach ${ }^{111}$. Zestawienie ugru w partii skóry dziecka, jego rumiane policzki, chromowo zielona koszulka, ciemny zaplecek krzesła i zielone tło tworzą całość o pogodnym i dekoracyjnym charakterze. Takie cechy noszą też inne obrazy z tego okresu, np. Bracia z dwoma jasnowłosymi chłopcami patrzạcymi na widza szeroko otwartymi błękitnymi oczyma ${ }^{112}$, Kowal z Jobourga $z$ żona ${ }^{113} \mathrm{z}$ półpostaciami uśmiechniętego rzemieślnika $\mathrm{i}$ jego posępnej żony. Surowa, uproszczona forma, żywy koloryt i wyrazisty kontur łączą obrazy Simona Segala $\mathrm{z}$ jednej strony $\mathrm{z}$ dziełami fowistów, $\mathrm{z}$ drugiej zaś z twórczością dzieci.

Trudno dziś powiedzieć, na ile spisana w ostatnim okresie życia autobiografia Simona Segala jest zapisem wydarzeń i emocji odtworzonych z pamięci, na ile zaś autokreacją. Autor nie był kronikarzem swojej egzystencji, daty różnych wydarzeń nie stanowiły dlań szczególnego problemu, bowiem — poza kilkoma z okresu młodzieńczego i zanotowanymi w czasie wędrówki w początkach II wojny światowej na południe Francji - nie podawał ich. Nie wiemy, jak długo przebywał w Berlinie, kiedy bawił w Wiedniu, kiedy poślubił Genevieve, podobnie jak tajemnicą jest, dlaczego małżeństwo nie przetrwało próby czasu. Być może trafnie scharakteryzowała artystę Jean Rhys ${ }^{114}$, która w opowiadaniu Good Moorning, Midnight nadała Simonowi imię Serge: był melancholijnym rosyjskim Żydem, nie sprzyjało mu szczęście, przybył do Francji w 1925 roku, żeby zostać malarzem; interesowali go biedacy, wojna i sceny przemocy, był obsesyjnie prostolinijny, nie sprzedawał wiele ${ }^{115}$. W tym czasie Segala istotnie interesowali ubodzy, skrzywdzeni i niewiele sprzedawał.

${ }^{106}$ Bible illustrée par Simon Segal, Paris 1957, s. 155.

${ }^{107}$ L'Apocalypse selon Saint Jean, Éd. Les Bibliophiles de France, Paris 1968, s. 133.

${ }^{108}$ Les mediants, gwasz, zbiory prywatne w Paryżu, [w:] Simon Segal 1898-1969, s. 10.

${ }^{109}$ Tamże, s. 17.

${ }^{110}$ S. Segal, Autobiographie, s. 20.

${ }^{111}$ Simon Segal 1898-1969, s. 18.

${ }^{112}$ Simon Segal, Les fréres, 1949, olej, tamże, s. 20.

${ }_{113}$ Simon Segal, Le forgeron de Jobourg et sa femme, 1949, olej, tamże, s. 27.

114 Jean Rhys (właśc. Ella Gwendolen Rees Williams, 1890-1979), modernistyczna pisarka pochodząca z Indii Zachodnich, od 1907 w Anglii, w swojej prozie zajmowała się postaciami przesiedleńców, osób wykluczonych społecznie, pozbawionych ojczyzny; P. Radia, Jean Rhys, [w:] 501 wielkich pisarzy, red. J. Patrick, Warszawa, 2009, s. 316.

${ }^{115}$ L. Pizzichini, The Blue Hour: A Portrait of Jean Rhys, London 2009, s. 170. Podobne wnioski odnośnie pierwowzoru malarza-emigranta Serge wysnuła Carole Angier w biografii Jean Rhys: C. Angier, Jean Rhys: Life and Work, New York 2001, s. 365. 
Można się zastanawiać, dlaczego Segal opuścił rodzinne miasto. Cytowany już Andrzej Bobkowski pisał:

Czy my w ogóle wiemy, co to znaczy wolność? [...] Gdyby nie to, że poznałem Francję jeszcze tę przedwojenną, umarłbym w przekonaniu, że to wszystko czym żyłem, to była wolność [...], to było jedyne państwo w Europie przedwojennej, które jeżeli nie dawało wolności naprawdę, to w każdym razie zapewniało jej złudzenie w bardzo szerokim zakresie ${ }^{116}$.

Wybór Paryża jako miejsca pobytu wydaje się oczywisty. Jak stwierdziła Ewa Bobrowska, Paryż stał się artystyczną stolicą Polaków z wielu powodów: był miastem otwartym dla uchodźców, wyróżniającym się inspirująca atmosferą intelektualną i bujnym życiem artystycznym, zaś bogate zbiory dawnej sztuki dawały możliwość studiowania techniki mistrzów malarstwa. Udział w paryskich Salonach stanowił konsekrację artystycznej kariery i dawał możliwość nawiązywania kontaktów, wymiany doświadczeń i poznania nowych nurtów; nie bez znaczenia jest fakt, że Paryż stał się światowym centrum handlu sztuką ${ }^{117}$.

Simon Segal wtopił się w międzynarodową społeczność Paryża i kwestia narodowości nie była dlań istotna, w katalogach wystaw deklarował rosyjskie pochodzenie, w 1949 roku otrzymał obywatelstwo francuskie ${ }^{118}$. Nie wiemy, czy miał na to wpływ fakt, że Białystok, leżący na zachodnich rubieżach Rosji na obszarze wyznaczonym dla żydowskich osadników, podlegał kolejno czterem różnym administracjom, zaś jego położenie przyciągało Polaków, Rosjan, Niemców, Litwinów i Żydów ${ }^{119}$. Dla przybywających z różnych stron Żydów, Białystok nie był więc ziemią ojców, nie stanowili tu ludności autochtonicznej, toteż zmagali się z problemami tożsamości i asymilacji ${ }^{120}$. Inna sprawa, że rozważania na temat narodowości artystów nie rozwiązują żadnych problemów związanych z ich twórczością ${ }^{121}$. Istotniejszym problemem była potrzeba stworzenia nowego języka umożliwiającego sformułowanie doświadczeń specyficznie żydowskich. Sprawa ta wyrosła na gruncie cywilizacyjnych przemian i przekonania, że wymagają one nowych sposobów ekspresji własnej tożsamości kulturowej. Problem ten pojawił się wśród Żydów wschodnioeuropejskich na przełomie XIX i XX wieku ${ }^{122}$. Poszukiwanie własnego języka przez artystów tego kręgu jest przejawem tych dążeń.

Zdaniem Jerzego Malinowskiego na przełomie XIX i XX wieku żydowscy artyści stanowili część polskiego życia artystycznego, nie tworzyli odrębnych grup, nie organizowali wystaw, ani też nie wydawali własnych pism artystycznych. Pierwsze wystawy Żydowskich Artystów Plastyków pokazano w Warszawie tuż przed I wojną światową ${ }^{123}$

${ }^{116}$ A. Bobkowski, Szkice piórkiem, s. 263.

${ }^{117}$ E. Bobrowska, Emancypantki? Artystki polskie w Paryżu na przetomie XIX i XX w., Archiwum Emigracji. Studia - Szkice — Dokumenty 2012 z. 16-17, s. 12.

${ }^{118}$ Simon Segal 1898-1969, s. 8.

${ }_{119}$ R. Kobrin, Żydowski Białystok i jego diaspora, Sejny-Białystok 2014, s. 42.

${ }^{120}$ Tamże.

${ }^{121}$ J. Suchan, Polak, Żyd, artysta. Tożsamość a awangarda, [w:] Polak, Żyd, artysta, Tożsamość a awangarda, red. tenże, Łódź 2010, s. 14.

${ }_{122}$ Tamże, s. 15. Zdaniem autora tożsamość narodowa przynajmniej części artystów żydowskich nie była przeżywana w sposób mocny, postrzegali siebie bardziej jako awangardowych internacjonalistów niż uczestników jakiejkolwiek narodowej wspólnoty; tamże, s. 19.

123 J. Malinowski, Grupa „Jung Idysz” i żydowskie środowisko „Nowej Sztuki” w Polsce 1918-1923, Warszawa 1987, s. 5, 132, przyp. 5. Zob. też: J. Malinowski, Awangarda żydowska w Polsce, [w:] Polak, Żyd, artysta, s. 25-29. 
w mieście rodzinnym Simona Segala zaś wkrótce po jej zakończeniu, w 1919 roku $^{124}$. Jak przekonuje autor, stopień związku artystów żydowskich z polską kulturą był bardzo zróżnicowany: jedni (Isaja Kulwiański, Lazar Segall, Jakub Steinhard) nie deklarowali żadnych więzi z miejscem urodzenia, inni zaś (Chaim Sutin, Szamaj Mondszajn, Mojżesz Kisling, Marceli Słodki, Mela Muter, Leopold Gottlieb, Ludwik Markus) — przeciwnie. Możliwa była jeszcze inna postawa: jeden z najwybitniejszych, Marc Chagall, nie angażował się w spory o charakter żydowskiej sztuki, był po prostu artystą. W innym miejscu Jerzy Malinowski przypomniał, że spory o charakter sztuki żydowskiej w Warszawie przerwał pobyt El Lissitzkiego w 1921 roku: fascynacja nową kosmopolityczną sztuką zastąpiła trwające dyskusje na temat sztuki narodowej ${ }^{125}$. W Paryżu wielu przedstawicieli diaspory przyjęło tradycje sztuki francuskiej i uległo całkowitej asymilacji kulturowej $\mathrm{i}_{\text {językowej }}{ }^{126}$. Interesujący jest też inny aspekt problemu twórczości żydowskich artystów: Marc Chagall przeżył w Witebsku krótki okres fascynacji zinstytucjonalizowanymi formami aktywności ${ }^{127}$, co być może wpłynęło na jego późniejszą postawę.

$\mathrm{O}$ artystach żydowskich sceptycznie i z nadzieją zarazem wypowiadał się Jankiel Adler, twierdząc, że nie ma ich zbyt wielu (?), wymieniał Marca Chagalla, Segala (nie mamy pewności, czy chodziło o Simona), Marka Szwarca, Isuchera Rybaka ${ }^{128}$.

Biografia Simona Segala jest ilustracją przemożnej potrzeby tworzenia. By spełnić ów imperatyw artysta pokonał wiele przeciwności, zgodził się na ubóstwo, zaś jego twórczość jest w dużej mierze inspirowana przeżyciami i poglądami. Choć droga na salony wystawowe Tulonu i Paryża nie była łatwa, uczyniła zeń jednego z najciekawszych twórców kręgu École de Paris.

\section{LITERATURA}

Artistes Russes, exposition organisèe par la revue Notre Union du 26 juin au 10 juillet 1936, vernissage le vendredi 26 juin à 15 heures, Galerie Zak, 15 rue de l'Abbaye (Place SaintGermain-des-Prés), [folder wystawy];

G. Bachelard, Il Dritto di Sognare, Bari 1975;

G. Bachelard, The Right to Dream, Dallas 1988;

E. Bénézit, Dictionnaire critique et documentaire des peintres, sculpteurs, dessinateurs et graveurs de tous les temps et tous les pays, red. J. Busse, t. 5, Paris 1999;

E. Bobrowska, Emancypantki? Artystki polskie w Paryżu na przetomie XIX i XXw., Archiwum Emigracji, 2012 z. 16-17. DOI: 10.12775/AE.2012.001;

A. Darmon, Autour de l'art Juif: Peintres, sculpteurs et photographes, Paris 2003;

P. Korzec, Pogrom bialostocki w 1906 r. i jego polityczne reperkusje, Rocznik Białostocki 1962 t. 3 ;

W. George, Segal ou l'Ange Rebelle, Genève 1962;

${ }^{124}$ J. Tomalska, Bencjon Rabinowicz i środowisko żydowskich artystów Biategostoku, [w:] Pogranicze, Kresy, Wschód a idee Europy, Seria II: Wiktor Choriew in Memoriam, red. A. Janicka, G. Kowalski, Ł. Zabielski, Białystok 2013, s. 367.

${ }^{125}$ J. Malinowski, Awangarda żydowska, s. 28.

${ }^{126}$ Tenże, Grupa ,,Jung Idysz”, s. 13.

127 W marcu 1918 roku Marc Chagall został komisarzem sztuki i szefem ludowego instytutu sztuki, większość zatrudnionych tu artystów także była Żydami; po 1920 roku możliwości żydowskich artystów, by brać udział w organizacji rożnych wydarzeń i publikowaniu zdecydowanie zmalały, po tym, jak władze sowieckie ukróciły aktywność Kultur-Ligi i innych organizacji; V. Margolin, The Struggle for Utopia: Rodchenko, Lissitzky, Moholy-Nagy 1917-1946, Chicago 1997, s. 28-29.

${ }_{128}$ M. Stolarska-Fronia, Jankiel Adler, [w:] Żydzi polscy: historie niezwykłe, Warszawa 2015, s. 6 . 
A. Gleizes; Musée du Luxembourg, Simon Segal (1898-1969), [katalog wystawy], Paris 1989;

King of Fashion: The Autobiography of Paul Poiret, London 2009; Fashion: The Collection of the Kyoto Costume Institute: A History from the $18^{\text {th }}$ to the $20^{\text {th }}$ Century, red. A. Fukai, Köln-London 2004;

J. Krasnodębska, ,,Angielka w Paryżu”. Listy Haliny Korn-Żuławskiej do męża (maj-czerwiec 1950), Archiwum Emigracji, 2012 z. 16-17. DOI: 10.12775/AE.2012.013;

J. Malinowski, Grupa „Jung Idysz” i żydowskie środowisko „Nowej Sztuki” w Polsce 19181923, Warszawa 1987;

V. Margolin, The Struggle for Utopia: Rodchenko, Lissitzky, Moholy-Nagy 1917-1946, Chicago 1997;

N. Nieszawer, D. Princ, Jewish Artists of the School of Paris 1905-1939, Paris 2015;

S. Panichi, La Collezione Bruno Bassano, [w:] Pisa allo Specchio I Muzei e Collezioni Pisano, red. M. Buresi, A. Zampieri, Pisa 2012;

Polak, Żyd, artysta, Tożsamość a awangarda, Łódź 2010;

Русская литература XX века. Прозаики, поэты, драматурги. Биобиблиографический словарь, t. 1, Москва 2005;

В. В. Сорокина, Издательства и журналье, [w:] Русский Берлин, Москва 2003, s. 120-160.

Simon Segal e la Scuola di Parigi, Donazione Bruno Bassano, Pisa 1975;

Simon Segal et l'École de Paris, Donation Bruno Bassano, Ville d'Aups 1977;

Simon Segal 1898-1969, [katalog wystawy]. Paris, Musée du Luxembourg, [Cour Cheverny 1989];

Simon Segal (1898-1969), Tajemnicze dziecko Białegostoku, Wystawa eksponowana w Muzeum Podlaskim w Bialymstoku 18 VI -5 IX 2010 [zestaw pocztówek];

M. Stolarska-Fronia, Jankiel Adler, [w:] Żydzi polscy: historie niezwykłe, Warszawa 2015;

J. Tomalska, Bencjon Rabinowicz i środowisko żydowskich artystów Białegostoku, [w:] Pogranicze, Kresy, Wschód a idee Europy, Seria II: Wiktor Choriew in Memoriam, red. A. Janicka, G. Kowalski, Ł. Zabielski, Białystok 2013;

A. Tossi, Simon Segal e La Scuola di Parigi, Donazione Bruno Bassano, Museo Nazionale di S. Matteo, Maggio 1975 [katalog wystawy], Pisa 1975;

A. Wierzbicka, École de Paris: Pojęcie, środowisko, twórczośś, Warszawa 2004;

Ch. Zagrodzki, Hayden 1883-1970, Paryż 2013, s. 39.

\section{SIMON SEGAL: A CONTRIBUTION TO THE ARTIST'S BIOGRAPHY}

Even though Simon Segal is one of the most interesting artists of the École de Paris circle, his biography remains insufficiently researched. Nothing is known about the ups and downs of the artist's life in Berlin, the time when he first got interested in painting, the period of his residence in Vienna nor his first individual exhibition he supposedly organized there. Also the reasons for change of his artistic interests remain unknown. Towards the end of his life, the painter wrote down his autobiography containing most of his biographical data. This article is an attempt to reconstruct key events in the life of Simon Segal as well as transformations in his artistic creativity.

Keywords: Białystok, emigration, École de Paris, Jewish art. 